\title{
Petrology and Geochemistry of Basement Complex Rocks in Okom-Ita Area, Oban Massif, Southeastern Nigeria
}

\author{
Kelechi Denis Opara*, Young E. Obioha, Samuel Okechukwu Onyekuru*, \\ Chikwendu Okereke, Sabinus Ikechukwu Ibeneme \\ Department of Geosciences, Federal University of Technology, Owerri, Nigeria \\ Email: *kelechiopara81@gmail.com, ${ }^{*}$ onyekuru2001@yahoo.com
}

Received 14 January 2014; revised 15 February 2014; accepted 12 March 2014

Copyright (C) 2014 by authors and Scientific Research Publishing Inc.

This work is licensed under the Creative Commons Attribution International License (CC BY). http://creativecommons.org/licenses/by/4.0/

c) (i) Open Access

\section{Abstract}

The determination of the mineralogical composition of rocks that underlie Okom-Ita area, in Oban Massif became necessary for the interpretation of the petrogenesis and protoliths of rocks in the area. Twelve representative rock samples were selected for thin section petrography and bulk rock geochemical analysis. The results reveal that the dominant intrusive rocks in Okom-Ita area are pegmatites, quartz veins and dolerites emplaced within gneisses, schists and phyllites host rocks. The quartz veins and pegmatites are leucocratic consisting predominantly of quartz, plagioclase and subordinate amount of Muscovites. The dolerite is dark grey, fine to medium grained and texturally ophitic and consists dominantly of pyroxenes, olivine and opaques. Three varieties of gneisses were recognized: feldspathic, banded and biotite gneisses. The gneisses, schists, and phyllites are dominated by $\mathrm{SiO}_{2}$ in the range of $(60 \%-75 \%)$. The rocks exhibit higher molecular concentration $\left\{\mathrm{Al}_{2} \mathrm{O}_{3}>\left(\mathrm{CaO}+\mathrm{Na}_{2} \mathrm{O}+\mathrm{K}_{2} \mathrm{O}\right)\right\}$, high alkali concentration with $\mathrm{Na}_{2} \mathrm{O}>\mathrm{K}_{2} \mathrm{O}$, high $\mathrm{Al}_{2} \mathrm{O}_{3}$ to alkali ratios and low $\mathrm{TiO}_{2}, \mathrm{CaO}$ and $\mathrm{MgO}$ concentrations. These distribution trends suggest a compensation for the high silica and alumina concentrations and support a granitic protolith for the pegmatites and their host gneisses and schists. The dolerites and amphibolites are impoverished in $\mathrm{SiO}_{2}$, but relatively enriched in lime and alkali oxides. Plots in the $\mathrm{AFM}, \mathrm{TiO}_{2}-\mathrm{K}_{2} \mathrm{O}-\mathrm{P}_{2} \mathrm{O}_{5}$ and $\mathrm{Na}_{2} \mathrm{O} / \mathrm{Al}_{2} \mathrm{O}_{3}-\mathrm{K}_{2} \mathrm{O} / \mathrm{Al}_{2} \mathrm{O}_{3}$ diagrams show that the pegmatite was derived from calc-alkaline magmatic source, while the dolerite was derived from tholeiitic basalt magma.

\section{Keywords}

Okom-Ita, Oban Massif, Petrology, Geochemistry, Petrogenesis, Protolith, Tectonics

\footnotetext{
${ }^{*}$ Corresponding authors.

How to cite this paper: Opara, K.D., et al. (2014) Petrology and Geochemistry of Basement Complex Rocks in Okom-Ita Area, Oban Massif, Southeastern Nigeria. International Journal of Geosciences, 5, 394-407. 


\section{Introduction}

Nigeria lies in the Pan-African mobile belt, being sandwiched between the West African Craton to the west, eastern Saharan Craton to the northeast and the Gabon-Congo Craton to the southeast [1]. It is underlain by crystalline Basement Complex and sedimentary rocks. The Precambrian Basement Complex rocks cover about $50 \%$ of Nigeria's land area and extend into neighboring countries like Benin to the west and Cameroun Republic to the east. The Nigerian Precambrian rocks have been grouped into two based on age and composition: the pre-Pan African rocks (2.8 - $1.3 \mathrm{Ga}$ ) which are mainly migmatite-gneiss complexes and ancient granitic rocks and the Pan-African rocks (600 $\pm 1500 \mathrm{Ma}$ ) comprising of the Older Granites and Metavolcano sedimentary series [2]. The Oban Massif area in the southeastern part of Nigeria is underlain by some of these Basement Complex rocks. The area is a part of the giant spur that represents the western prolongation of the Cameroun Mountains into the Cross River plains of southeastern Nigeria (Figure 1). In fact the Oban Massif is a deeply dissected plateau which in places attains a height of $1125 \mathrm{~m}$ above mean sea level [3]. Okom-Ita area, in Akamkpa Local Government Area of Cross River State lies in the southwestern end of the Oban Massif. The area is defined by latitudes $5^{\circ} 19^{\prime} \mathrm{N}$ and $5^{\circ} 23^{\prime} \mathrm{N}$ and longitudes $8^{\circ} 19^{\prime} \mathrm{E}$ and $8^{\circ} 23^{\prime} \mathrm{E}$, covering an approximate areal extent of about $42 \mathrm{~km}^{2}$ (Figure 1).

The determination of the composition of rocks in Okom-Ita area using X-Ray fluorescence spectrometry and thin section petrography became necessary to obtain more comprehensive geological information of the study area. And combining the geological information with a detailed chemical classification of rocks in the area using

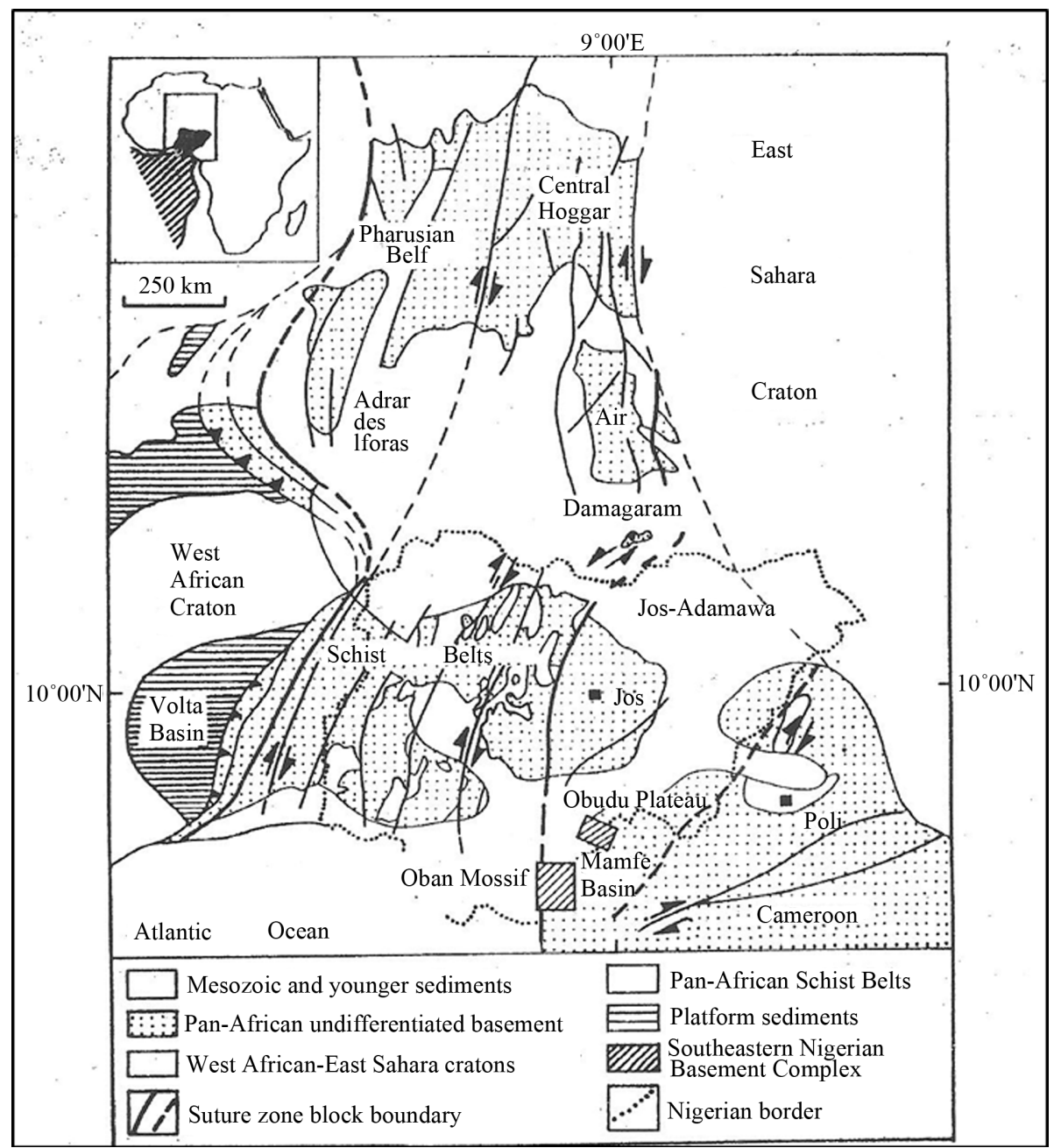

Figure 1. Generalized geological map showing the Pan-African Belts of Nigeria and the location of the southeastern Nigerian Basement Complex [7]. 
dominant mineralogical compositions, the prediction of the petrogenesis and the protoliths of the rocks in Okom-Ita area would be achieved.

\section{Geological Setting}

The geological map of Nigeria shows that the Basement Complex can distinctively be divided into two zones: a western zone in which the N-S trending elongate schist belts are separated from one another by migmatite gneisses, granite gneisses and granites and an eastern zone in which the schist belts are poorly represented and underlain by migmatites, gneisses and granites [4]. Like the Precambrian of Africa, two models have been proposed: the ensialic deformation and plate tectonic models. The mix-up of rocks lacking a systematic variation and the virtual absence of truly miogeosynclinal sediments until upper Precambrian times do not favor a plate tectonic model of evolution of the Nigerian Basement Complex [5]. Conversely, [6] suggested that the Basement Complex of Nigeria formed as a result of the opening and closing of a small ocean comparable to the Red Sea.

Other researchers inferred that the Pan African belt in the east of the West African Craton is a collision-type orogeny with an eastward dipping subduction zone [8]-[10]. According to them, the closure of the ocean at the craton margin and the intracontinental basins and oceans led to the deformation and metamorphism of the metasediments, partial melting of the mantle and lower crust and the emplacement of the Older Granites. In the Oban Massif, the Basement Complex rocks is dominated by the Uwet granodiorite and charnockite masses which intruded a sequence of schists similar to those described from southwestern and northwestern Nigeria [3]. The scholars who had studied the petrology of Obudu and Oban Massifs, including the works of [3], [11] agreed that a great similarity exists in characteristics of both massifs.

The rocks of the Oban Massif are comprised of the following suites:

- Migmatitic and sheared gneissic rocks, para- and ortho-schists, phyllites, meta-conglomerates and quartzites, amphibolites and metadolerites, pegmatites, aplites and pyroxenites;

- Synkinematic to late kinematic Older Granite intrusive series comprising rocks of varying compositions;

- Unmetamorphosed dolerite to microdioritic intrusive rocks [12].

In the Okom-Ita area the dominant intrusive rocks are the pegmatites, quartz veins and dolerites emplaced within the gneiss, schist and phyllite host rocks [3].

\section{Methodology}

Twelve (12) representative fresh rock samples were systematically selected from a total of thirty nine (39) samples collected during the field mapping for laboratory analysis. Bulk rock geochemical analysis was carried out using X-Ray fluorescence spectrometry at the geochemistry laboratory of the Technical University of Berlin, Germany. Each of the samples was first crushed and powdered. Fused discs and pressed beads were thereafter produced for major and minor element analyses. Each of the prepared samples was oven-dried overnight at $105^{\circ} \mathrm{C}$ to determine their natural moisture contents. The samples were again placed overnight in an oven at $800^{\circ} \mathrm{C}$ and the difference in weight calculated to obtain the Loss on Ignition (LOI). $1.5 \mathrm{~g}$ of powder from each of the samples for which LOI has been determined was mixed with $6 \mathrm{~g}$ of lithium tetraborate $\left(\mathrm{Li}_{2} \mathrm{~B}_{4} \mathrm{O}_{7}\right)$ and lanthanum oxide $\left(\mathrm{La}_{2} \mathrm{O}_{3}\right)$ in a platinum crucible and fused at $1200^{\circ} \mathrm{C}$ to produce melt beads for the analysis of the major elements.

\section{Results}

\subsection{Occurrence and Petrography of Rocks in Okom-Ita Area}

In the Okom-Ita area the dominant intrusive rocks are the pegmatites, quartz veins and dolerites emplaced within gneisses, schists and phyllites host rocks (Figure 2). Both the intrusive and their host rocks were petrographically and geochemically analyzed. The results of the petrographic analyses are presented in Table 1, while Table 2 shows the results of the whole rock geochemistry. The quartz veins are leucocratic consisting mainly of quartz minerals. The pegmatites are also leucocratic but consist of feldspar, quartz, mica and tourmaline minerals. The dolerite is dark grey in colour, unmetamorphosed, fine-medium grained, tholeiitic in composition, and mineralogically, dominated by plagioclase, pyroxene and olivine. A metamorphosed basic igneous rock (Amphibolite) was also encountered in the study area. Field and mineralogical properties of the major rock types that underlie Okom-Ita area are presented below: 


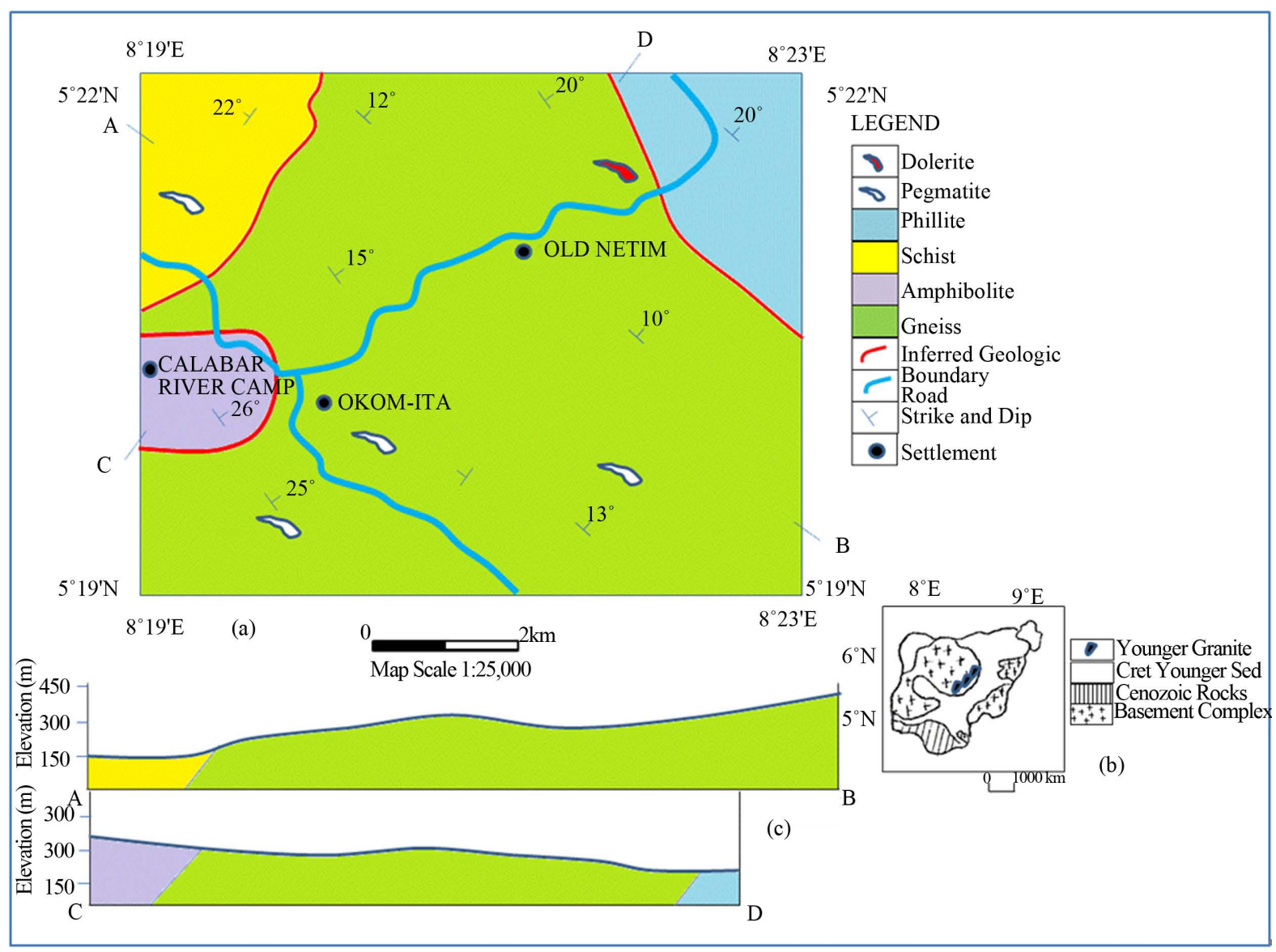

Figure 2. Map showing (a) The geology of Okom-Ita area of the Oban Massif; (b) The inset crystalline Basement Complex of Nigeria; (c) Cross sections drawn from the geologic map (A-B; C-D).

\subsubsection{Gneisses}

The gneissic rocks observed in the area of study are the quartzo-feldspathic rocks that underlie about $70 \%$ of the total mapped area (Figure 1). The rocks are mainly biotite gneiss, feldspathic gneisses and banded gneisses. These rocks are conspicuous around Old Netim and in fact the predominant rock type in the northeastern part of the study area.

In hand specimen, the rocks are medium-coarse grained and in some places dissected with quartzo-feldspathic veins. Modal analysis shows that the biotite gneiss is chiefly comprised of quartz (25\%), k-feldspar (25\%), biotite (25\%), plagioclase (10\%) and minor amounts of muscovite and epidote (Table 1). Similarly, the light and dark-coloured minerals representing Quartz and biotite respectively are clearly seen in the photomicrograph of the biotite gneiss sample (Figure 3(a)). The migmatite gneiss is composed of quartz (24\%) and K-feldspars (30\%) as shown in Table 1. Biotite, muscovite and epidote are also common while plagioclase occur as untwined albite (15\%). Banded gneiss shows a well developed foliated texture in which segregation banding predominates. Dark bands typically dominated by ferromagnesian inosillicates (hornblende and pyroxene) and light bands of phyllosilicates typically dominated by mosaic textures of quartz and feldspar were observed in hand specimens of the banded gneiss.

\subsubsection{Schists}

Schists are strongly foliated rocks formed by regional metamorphism as they readily split into flecks. The conspicuous shistocity of all schists is attributed to mineral orientation. Schist underlies less than $20 \%$ of the total mapped area (Figure 2). It is found occurring in areas around Dukwe Camp and the Eng-Haut Rubber plantation. The schists are highly weathered. Schistocity however is strong and trends N-S to NE-SW. Slickensides were also evident indicative of shearing and faulting that occurred as a result of deformation of rocks in the area [3]. 


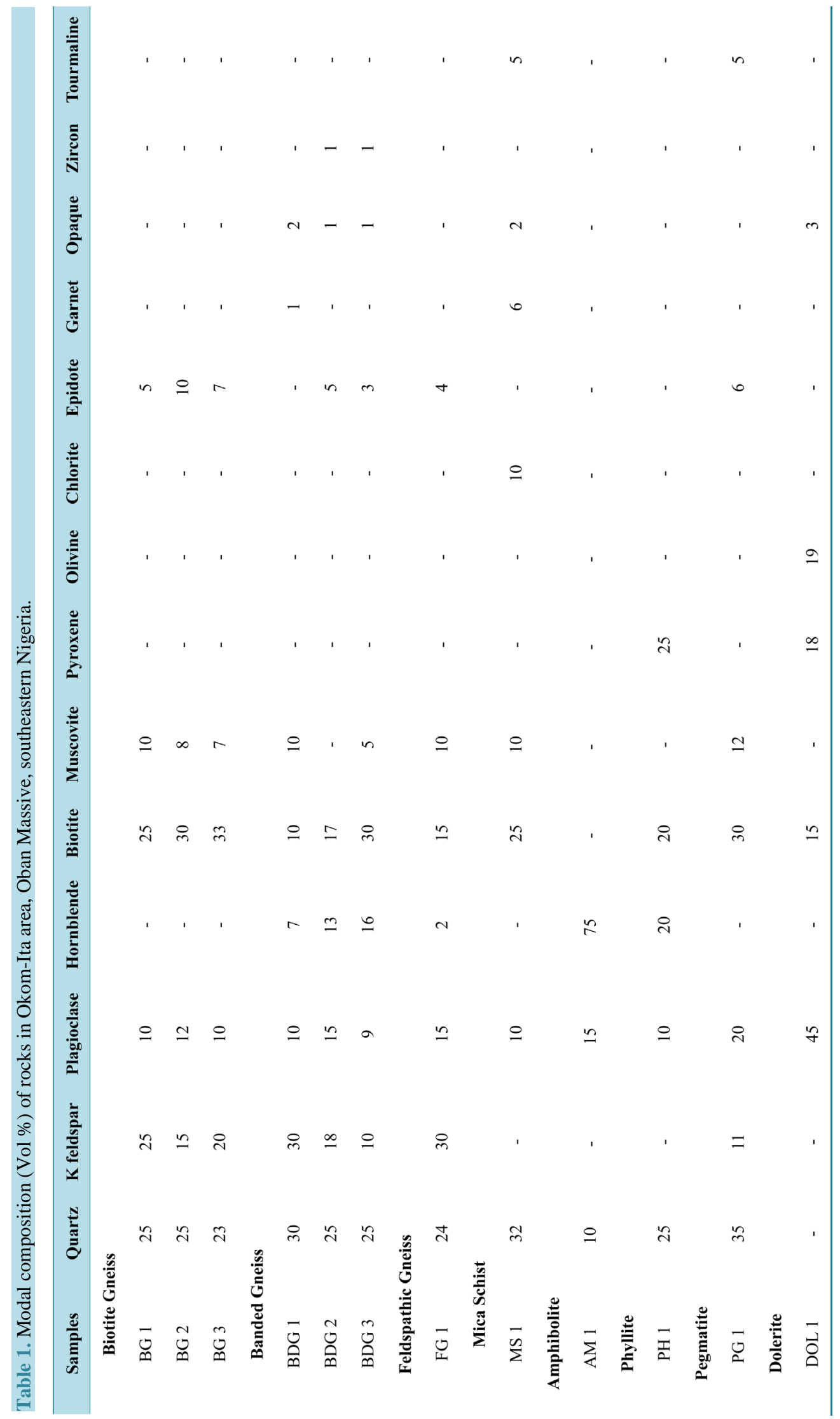




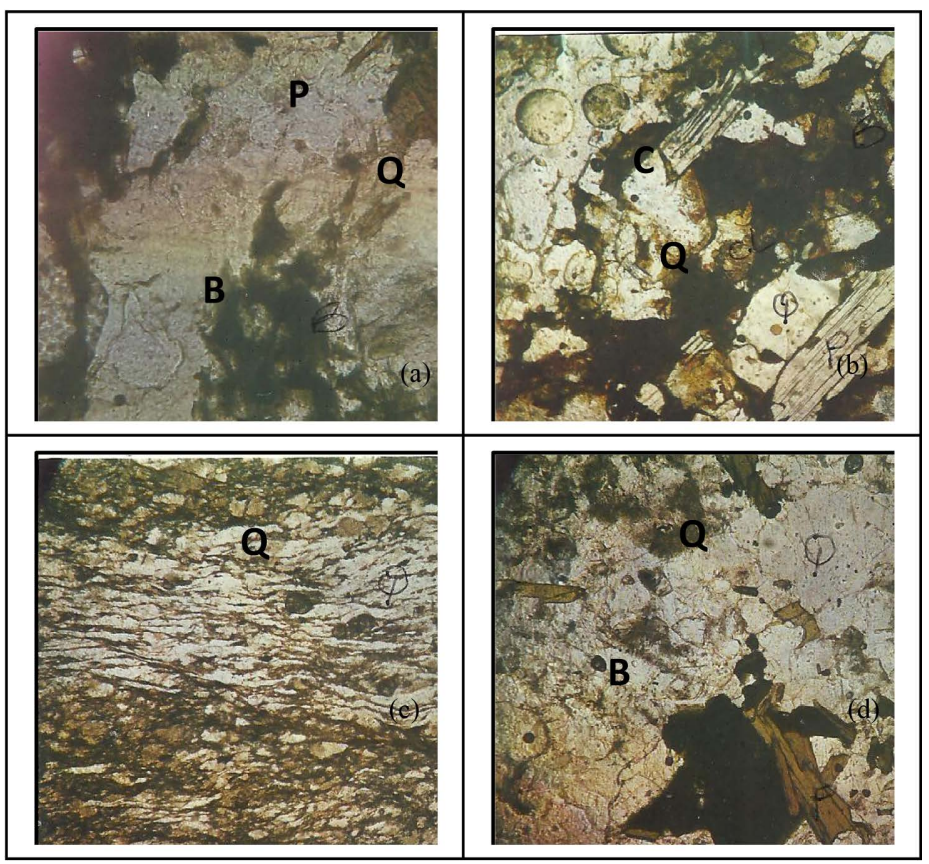

Figure 3. Photomicrographs of rock samples from Okom-Ita area Oban Massive (PPL X30) (a) Biotite Gneiss (BG 1); (b) Phyllite (PH 1); (c) Amphibolite (AM 1); (d) Pegmatite (PG 1), $P$ = Plagioclase; $B=$ Biotite; $C L=$ Chlorite; $Q=$ Quartz.

In hand specimens, the schist samples show a foliated texture. Quartz is dominant and occurs together with biotite, chlorite and feldspar.

The preponderance of phyllosilicates, when the schists were observed in thin sections, confirmed the rock type to be pellitic schist [13]. Biotite appears as greenish and elongated flakes. Plagioclase is probably untwined albite indicating low grade metamorphism [14]. The presence of chlorite enhanced the foliation. Opaque minerals occur mainly as scattered grains of iron oxide.

\subsubsection{Phyllite}

Phyllite is a regionally metamorphosed foliated pellitic rock. They are fine grained micaceous rocks occasionally showing segregation layering. Just like schist, phyllites are restricted to the western part of Oban Massif. Garnetiferous varieties have been reported from the Uwet area [14]. They are characterized by a silky sheen on the cleavage of the surface. In thin section, the main minerals recognized include biotite, quartz, chlorite and plagioclase (Figure 3(b)). Chlorite minerals have impacted a rather peculiar luster to the surface of the schistocity. The mica minerals are mainly biotite and muscovite (20 wt\%) (Table 1).

\subsubsection{Amphibolite}

Amphibolite occurs as a fine-medium grained metamorphic rock composed mainly of amphibole. It is formed by the regional metamorphism of basic igneous rocks. They may be banded or homogeneous. The banded variety has thin layers of quartzo-feldspathic materials alternating with thick dark bands consisting of mainly hornblende and minor phyllosilicate [15]. In the study area, it constitutes less than $15 \%$ of the total area underlain by rocks. Amphibolite is exposed within the Calabar River Camp where it occurred as massive bodies, often along streams and river channels. It has been noted that the Amphibolites are associated with dolerite stocks, which are chemically related, but the amphibolites are older because they have been deformed and metamorphosed [3].

In thin section, the amphibolites are foliated with hornblende defining the foliation (Figure 3(c)). Hornblende is the dominant mineral present (70\%), quartz is minor and plagioclase occurs as anorthite with a composition of $\mathrm{An}_{45}$. Amphibolites consist of about 60\% - 70\% amphibole; Almandine garnet may be present depending on the rock composition [16]. 


\subsubsection{Pegmatite}

These are very coarse-grained igneous rocks with phenocrysts over $250 \mathrm{~mm}$ in length usually of granitic composition and forming at the late stage of crystallization. In the study area, they occur mostly as unmappable veins of varying dimensions within the gneisses and schists. They also occur as boulders (about $3 \mathrm{~m} \times 5 \mathrm{~m}$ ) around the Calabar River Camp.

Also occurring in varying dimensions in the gneisses and schist are quartz veins. They cut across the whole length and width of the host rock. Their emplacement is controlled by the N-S to NE-SW regional structure of the host rock. In thin sections, quartz occurs as very coarse grained crystal (Figure 3(d)). Other minerals identified in thin sections include biotite, plagioclase, muscovite and epidote. Feldspar occurs mainly as K-feldspar and may grow into zones where they are replaced by sodic plagioclase. Biotite is a minor constituent while muscovite occurs as books or flaky aggregates.

\subsubsection{Dolerite}

Dolerite is a medium grained mafic igneous rock that is mineralogically and chemically equivalent to basalt and commonly forms minor intrusion. Dolerite is widespread in the basement complex of Nigeria. Their emplacement is believed to have terminated the Pan-African Orogeny in Nigeria [17]. In the mapped area, dolerite was found at Old Netim occurring as dyke bodies of several centimeters thick and cutting the foliation of the gneiss host rock (Figure 4). They displayed sharp contacts with the gneiss host rock showing no evidence of metamorphism. It is possible that dolerites occur at other locations but are buried under the surface because of their hyper-abyssal nature.

In hand specimen, dolerite is a medium grained, dark grey coloured and non-foliated igneous rock. The thin section analysis shows that the dolerite is sub-ophitic in texture with randomly oriented laths of plagioclase and partly enclosed in irregular bounded crystals of pyroxene. Mineralogically, they are composed dominantly of plagioclase (45\%). Others minerals occurring in the dolomite include pyroxene, olivine, biotite and opaque minerals (Table 1). Olivine occurs mainly as large equant phenocrysts and irregular cleavage. The pyroxene content is augite and hyperstene. Dominant plagioclase is the labrodorite (An55-An60). The opaque minerals occur as scattered grains of iron oxide along the augite partings.

\subsection{Geochemistry of Rocks in Okom-Ita}

The results of the geochemical analysis of the rocks in the study area are presented in Table 2, which aided the calculation of the Niggle norm [18]. The Niggle norm was chosen because determination of the norm of metamorphic rocks, highly altered igneous rocks and metasediments can indicate the general nature of the anhydrous

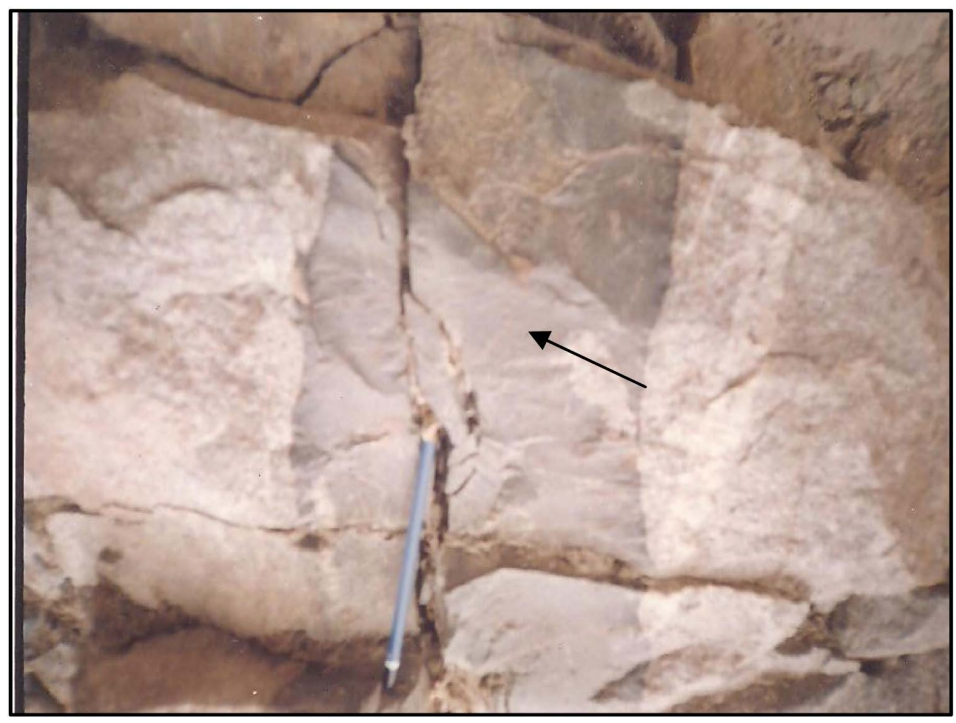

Figure 4. Dolerite intrusion (dark portion) truncating the foliation of the host gneiss in a N-S trend, Old Netim Oban Massive. 
Table 2. Major element composition of rocks in the Okom-Ita area Oban Massive.

\begin{tabular}{|c|c|c|c|c|c|c|c|c|c|c|c|c|}
\hline Samples & $\mathrm{SiO}_{2}$ & TiO2 & $\mathbf{A l}_{2} \mathbf{O}_{3}$ & $\mathrm{Fe}_{2} \mathrm{O}_{3}$ & Foe & Mino & MgO & $\mathrm{CaO}$ & $\mathrm{Na}_{2} \mathrm{O}$ & $\mathrm{K}_{2} \mathrm{O}$ & $\mathbf{P}_{2} \mathbf{O}_{5}$ & LOI \\
\hline \multicolumn{13}{|c|}{ Biotite Gneiss } \\
\hline BG 1 & 63.55 & 0.84 & 16.1 & 5.85 & ND & 0.67 & 2.09 & 3.64 & 4.36 & 2.29 & 0.34 & 0.29 \\
\hline BG 2 & 63.00 & 0.20 & 16.06 & 0.20 & 2.77 & 0.25 & 0.91 & 5.70 & 2.80 & 1.41 & 0.41 & 0.47 \\
\hline BG 3 & 59.04 & 1.06 & 16.28 & 5.90 & ND & 0.06 & 3.54 & 4.88 & 3.65 & 3.60 & 0.43 & 1.35 \\
\hline \multicolumn{13}{|c|}{ Banded Gneiss } \\
\hline BDG 1 & 64.88 & 0.20 & 14.80 & 4.42 & 3.92 & 0.27 & 0.72 & 5.90 & 2.90 & 1.41 & 0.31 & 0.29 \\
\hline BDG 2 & 64.60 & 1.14 & 15.00 & 4.80 & ND & 0.05 & 1.55 & 3.20 & 3.86 & 3.53 & 0.32 & 0.29 \\
\hline BDG 3 & 70.00 & 0.60 & 13.10 & 4.71 & ND & 0.08 & 0.80 & 2.20 & 2.72 & 4.48 & 0.15 & 0.35 \\
\hline \multicolumn{13}{|c|}{ Feldspathic Gneiss } \\
\hline FG 1 & 73.70 & 0.33 & 13.26 & 2.81 & ND & 0.05 & 1.00 & 1.98 & 3.70 & 3.11 & 0.16 & 0.18 \\
\hline \multicolumn{13}{|c|}{ Mica Schist } \\
\hline MS 1 & 60.10 & 0.86 & 7.75 & 8.50 & 0.20 & 4.30 & 0.70 & 1.30 & 4.10 & 0.15 & 0.15 & 1.98 \\
\hline \multicolumn{13}{|c|}{ Amphibolite } \\
\hline AM 1 & 50.05 & 1.26 & 12.20 & 12.21 & ND & 0.81 & 8.85 & 8.30 & 1.84 & 2.35 & 0.15 & 1.35 \\
\hline \multicolumn{13}{|l|}{ Phyllite } \\
\hline PH 1 & 65.60 & 0.80 & 16.20 & 3.70 & 0.07 & 2.00 & 3.50 & 3.45 & 3.70 & 0.18 & 0.12 & 0.64 \\
\hline \multicolumn{13}{|l|}{ Pegmatite } \\
\hline PG 1 & 75.30 & 0.10 & 13.40 & 0.67 & ND & 0.03 & 0.18 & 3.30 & 3.33 & 3.28 & 0.17 & 0.74 \\
\hline \multicolumn{13}{|l|}{ Dolerite } \\
\hline DOL 1 & 50.00 & 2.33 & 13.10 & 2.12 & 9.58 & 0.15 & 7.42 & 8.60 & 3.34 & 0.27 & 0.77 & 1.72 \\
\hline
\end{tabular}

igneous equivalent [19]. Again, since a greater proportion of rocks in the study area were metamorphic rocks, Niggle norm became useful in the interpretation [16].

The geochemical data (expressed in weight percent and molecular proportion) of the oxides were further plotted in variation/discriminatory diagram such as:

- $\mathrm{SiO}_{2}$ (wt\%) versus $\mathrm{Na}_{2} \mathrm{O}+\mathrm{K}_{2} \mathrm{O}$ (wt\%) diagram [20];

- ACF plot of [21];

- AFM plot $\left(\mathrm{Na}_{2} \mathrm{O}+\mathrm{K}_{2} \mathrm{O}-\mathrm{FeO}-\mathrm{MgO}\right)$;

- $\mathrm{Na}_{2} \mathrm{O} / \mathrm{Al}_{2} \mathrm{O}_{3}$ versus $\mathrm{K}_{2} \mathrm{O} / \mathrm{Al}_{2} \mathrm{O}_{3}$ diagram of [22];

- al-alk versus Niggle diagram of [23];

- $\mathrm{TiO}_{2}-\mathrm{K}_{2} \mathrm{O}-\mathrm{P}_{2} \mathrm{O}_{5}$ plot of [24].

The chemical composition of rocks is a direct reflection of the modal composition of the rocks [3]. Phyllite and schist are characterized by $\mathrm{SiO}_{2}$ in the range of $(60 \%-66 \%)$, excess $\mathrm{Na}_{2} \mathrm{O}$ over $\mathrm{K}_{2} \mathrm{O}$, high $\mathrm{Al}_{2} \mathrm{O}_{3}$ to alkali ratio and low content of $\mathrm{CaO}$ and $\mathrm{MgO}$. All the rocks exhibited high molecular trend of the order: $\mathrm{Al}_{2} \mathrm{O}_{3}>(\mathrm{CaO}$ $+\mathrm{Na}_{2} \mathrm{O}+\mathrm{K}_{2} \mathrm{O}$ ), reflecting their preliminary characteristics. The gneisses of Okom-Ita contain a high percentage of $\mathrm{SiO}_{2}$ in the range of (59 wt\% - $\left.73 \mathrm{wt} \%\right) . \mathrm{Al}_{2} \mathrm{O}_{3}$ is also high (13\% - 17\%). The gneisses contain higher silica and alkali concentrations than the associated metasediments. They are also enriched in $\mathrm{K}_{2} \mathrm{O}$ compared to other rocks in the area. The biotite gneisses differ in composition from the other gneisses in the area, in that they are impoverished in $\mathrm{SiO}_{2}$ but enriched in $\mathrm{Al}_{2} \mathrm{O}_{3}, \mathrm{Fe}_{2} \mathrm{O}_{3}$, and $\mathrm{MgO}$ when compared with the migmatitic and banded gneisses. Generally, the $\mathrm{TiO}_{2}$ is low, which suggests a compensation for the high silica and alumina values.

The amphibolite is impoverished in silica (50.05 wt\%), but enriched in $\mathrm{MgO}, \mathrm{Fe}_{2} \mathrm{O}_{3}, \mathrm{TiO}_{2}$, and $\mathrm{CaO}$, which is consistent with mafic character. Their low silica value is compensated by its enrichment in $\mathrm{TiO}_{2}(1.2 \mathrm{wt} \%)$. 
The major intrusive rocks in the area include pegmatite and dolerite. The pegmatite contains high percentage of $\mathrm{SiO}_{2}(>75 \mathrm{wt} \%$ ) and alkali elements (of about $6.61 \mathrm{wt} \%$; Table 2). Dolerite on the other hand is impoverished in $\mathrm{SiO}_{2}$ (50\%), but high $\mathrm{CaO}(8.60 \mathrm{wt} \%) \mathrm{MgO}$ (7.42 wt\%) contents and relatively rich in $\mathrm{Na}_{2} \mathrm{O}$ (63.34 wt\%) but highly depleted in $\mathrm{K}_{2} \mathrm{O}(0.27 \mathrm{wt} \%)$, which is consistent with its mafic characteristics.

\section{Discussion}

\subsection{Chemical Affinity}

The high $\mathrm{SiO}_{2}$ content of mica schist in the study area is typical of pellitic to semi-pellitic schists [2] [3] [25]. Also the excess of $\mathrm{Na}_{2} \mathrm{O}$ over $\mathrm{K}_{2} \mathrm{O}$ may be attributed to possible metasomatic reaction in which $\mathrm{Na}_{2} \mathrm{O}$ was preferably enriched and $\mathrm{K}_{2} \mathrm{O}$ depleted [3] [26] [27]. The higher $\mathrm{CaO}$ (3.45\%) in the phyllite at Old Netim could be due to the contamination of the rock by secondary calcite [3]. The enrichment in $\mathrm{TiO}_{2}, \mathrm{Al}_{2} \mathrm{O}_{3}, \mathrm{Fe}_{2} \mathrm{O}_{3}, \mathrm{MgO}$ and $\mathrm{CaO}$ of biotite gneiss compared to the other varieties of gneiss reflects a high modal proportion of Fe-Mg bearing silicates such as biotite and hornblende [3]. The same applies to amphibolites. The relatively high alkali contents of intrusive in the area might be attributed to widespread alkali metasomatism in the Nigerian basement due to its rejuvenation during the Pan African Orogeny [28] [29]. Finally, amphibolites and dolerite are characterized by a negative Niggli $(-q)$ value compared to the positive $(+q)$ values of other rock types. This negative value shows that the rock is none quartz normative, and therefore non-siliceous rock (Table 3).

Table 3. Calculated Niggli Norm for the rocks of Okom-Ita area.

\begin{tabular}{|c|c|c|c|c|c|c|c|c|}
\hline Samples & Al & Fm & C & All & Si & $\mathbf{K}$ & Mg & $\mathbf{Q}$ \\
\hline \multicolumn{9}{|c|}{ Biotite Gneiss } \\
\hline BG 1 & 30 & 40 & 12 & 18 & 201 & 0.25 & 0.39 & 29 \\
\hline BG 2 & 41 & 17 & 26 & 16 & 271 & 0.25 & 0.35 & 107 \\
\hline BG 3 & 27 & 41 & 15 & 17 & 168 & 0.39 & 0.78 & 0.1 \\
\hline \multicolumn{9}{|c|}{ Banded Gneiss } \\
\hline BDG 1 & 32 & 30 & 24 & 14 & 243 & 0.24 & 0.24 & 87 \\
\hline BDG 2 & 32 & 34 & 12 & 22 & 231 & 0.37 & 0.38 & 43 \\
\hline BDG 3 & 32 & 35 & 10 & 23 & 292 & 0.52 & 0.25 & 100 \\
\hline \multicolumn{9}{|c|}{ Feldspathic Gneiss } \\
\hline FG 1 & 37 & 26 & 10 & 26 & 350 & 0.35 & 0.41 & 146 \\
\hline \multicolumn{9}{|c|}{ Mica Schist } \\
\hline MS 1 & 38 & 41 & 5 & 15 & 221 & 0.03 & 0.21 & 61 \\
\hline \multicolumn{9}{|l|}{ MS 2} \\
\hline \multicolumn{9}{|c|}{ Amphibolite } \\
\hline AM 1 & 14 & 62 & 17 & 7 & 98 & 0.45 & 0.59 & -30 \\
\hline \multicolumn{9}{|l|}{ Phyllite } \\
\hline PH 1 & 36 & 36 & 14 & 14 & 245 & 0.03 & 0.75 & 89 \\
\hline \multicolumn{9}{|l|}{ Pegmatite } \\
\hline PG 1 & 44 & 7 & 20 & 20 & 42 & 0.39 & 0.32 & 202 \\
\hline \multicolumn{9}{|l|}{ Dolerite } \\
\hline DOL 1 & 19 & 50 & 22 & 22 & 121 & 0.05 & 0.58 & -11 \\
\hline
\end{tabular}




\subsection{Tectonic Setting and Petrogenesis}

The tectonic setting and petrogenesis of rocks in the study area were constrained using the AFM triangular discriminant and the $\mathrm{TiO}_{2}-\mathrm{K}_{2} \mathrm{O}-\mathrm{P}_{2} \mathrm{O}_{5}$ diagrams. The AFM plot is particularly useful in discriminating between tholeiitic and Calc-alkaline suites considering the $\mathrm{Fe}_{2} \mathrm{O}_{3}$ and $\mathrm{MgO}$ components [30] and hence the tectonic setting, since no trace element composition was determined for the rocks. From the plot, the pegmatite plotted in the calc-alkaline magmatic field, while the dolerite and amphibolite plotted in the tholeiitic field (Figure 5). On the alkali versus silica diagram of [20], dolerite and amphibolites also plotted in the tholeiitic field, indicating generation from tholeiitic magma source (Figure 6). On the $\mathrm{TiO}_{2}-\mathrm{K}_{2} \mathrm{O}-\mathrm{P}_{2} \mathrm{O}_{5}$ diagram of [24], the amphibolite and dolerite plotted in the field of continental basalt (Figure 7). Representatives of the analyzed samples were plotted in other variation diagrams to determine their protolith. On the $\mathrm{Na}_{2} \mathrm{O} / \mathrm{Al}_{2} \mathrm{O}_{3}-\mathrm{K}_{2} \mathrm{O} / \mathrm{Al}_{2} \mathrm{O}_{3}$ diagram of [22], the mica schist and phyllite plotted in the metasedimentary field, while all the gneisses and pegmatites plotted in the igneous field (Figure 8). The Niggli al-alk-Niggli C diagram of [23] shows the same character by having schist and phyllite plot on the outside of the igneous field, while gneiss and pegmatite plotted within the igneous field (Figure 9). The chemical composition of metaigneous and metasediments in the area were also plotted in the ACF diagram of [21] to know their progenitors. From the plot (Figure 10) biotite and feldspathic gneiss plotted in the field of clay-shale either free from carbonates or containing up to 30\% carbonates or in the andesitic-basaltic field. The banded gneiss had one sample each plotting on the field of andesitic-basaltic and field of clayshales containing up to $30 \%$ carbonates or carbonate free mud rocks. These rocks were believed to originate from the metamorphism of intermediate igneous rock such as granodiorite. Mica schist plotted in the field of clay-shales containing up to $30 \%$ carbonate while phyllite plotted in the greywacke field. These rocks are thought to originate from greywackes [31]. Amphibolites on the other hand plotted in the andesitic-basaltic field indicative of metamorphism from magmas derived from basaltic source.

Mica schists are characterized by the preponderance of phyllosilicate quartz, and feldspars [16]. The phyllosillicates are indication of metamorphism from shale or pellitic rocks. Gneisses are formed by deep seated high grade regional metamorphism. They are generally confined to eroded folded mountain belts and Precambrian terrain. Generally, they are made up of mineral constituents suggestive of metamorphic processes either of low grade or high grade. Phyllites are formed by low grade metamorphism of pellitic material and occasionally tuff or tuffaceous sediments. Also with higher grade metamorphism caused by increasing temperature or greater activity of permeating fluid, slates pass into phyllites [16]. Amphibolites are formed by regional metamorphism of basic rocks such as dolerites and basalts. The metamorphism is typical of the amphibolite facies which according to [32] [33] is characterized by plagioclase containing at least $15 \%$ anorthite. The mineralogy of pegmatite is

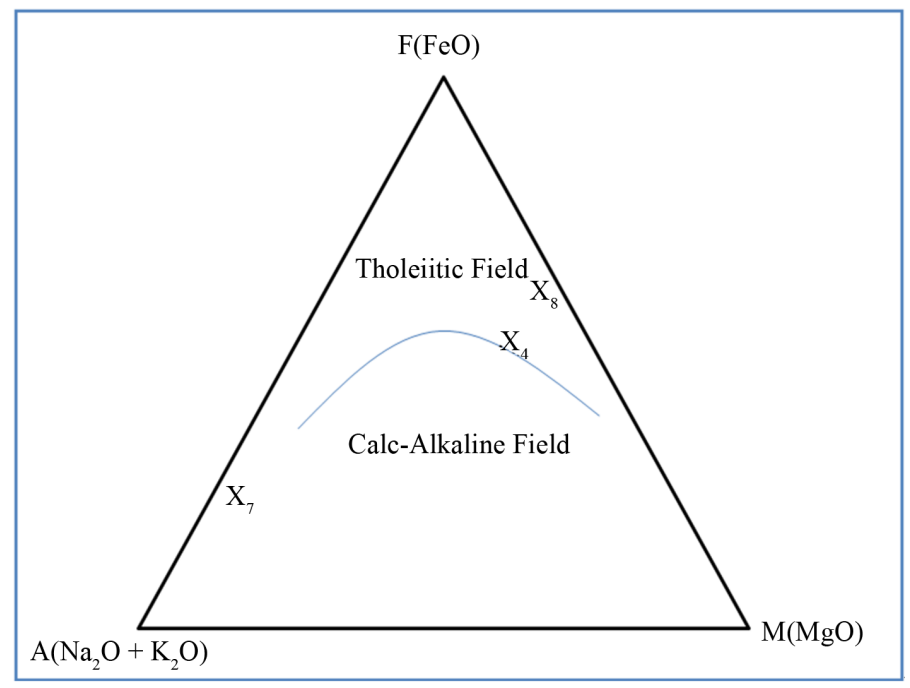

Figure 5. AFM diagram for rocks in the study area discriminating pegmatite of calc-alkaline field from mafic rocks of tholeiitic magma field ( $X_{4}$-amphibolite, $X_{7}$-pegmatite, $X_{8}$-dolerite) adapted from [35]. 


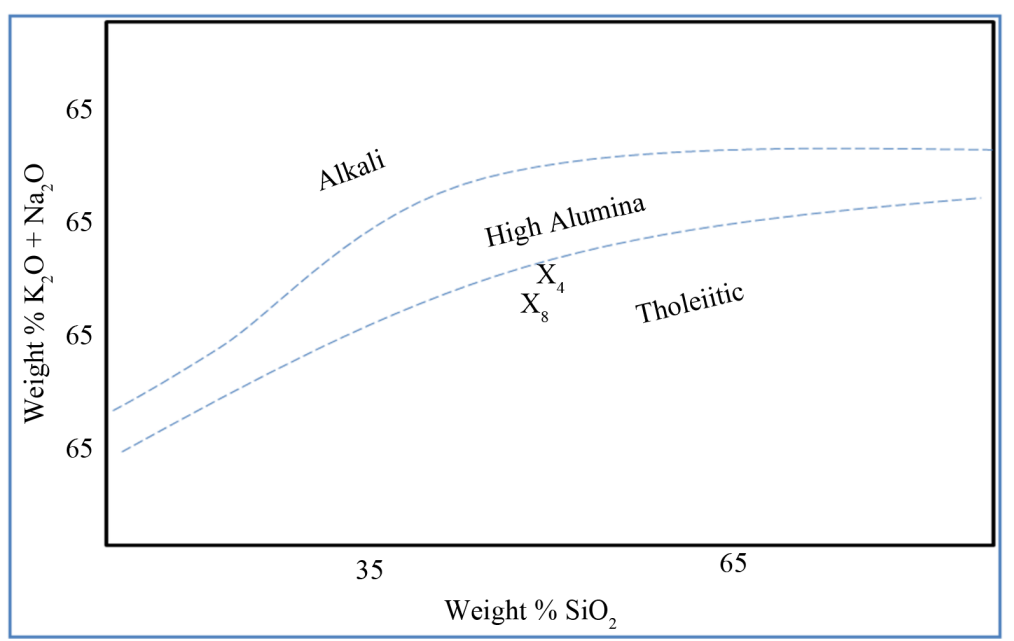

Figure 6. Alkali-Silica diagram of mafic rocks in the study area, adapted from [20].

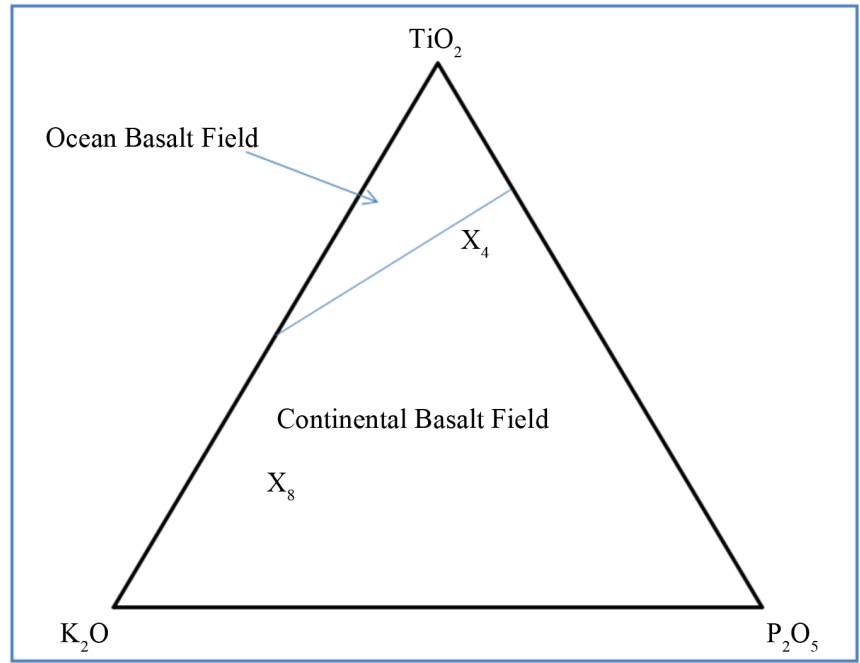

Figure 7. $\mathrm{TiO}_{2}-\mathrm{K}_{2} \mathrm{O}-\mathrm{P}_{2} \mathrm{O}_{5}$ diagram of mafic rocks in the study area, adapted from [24].

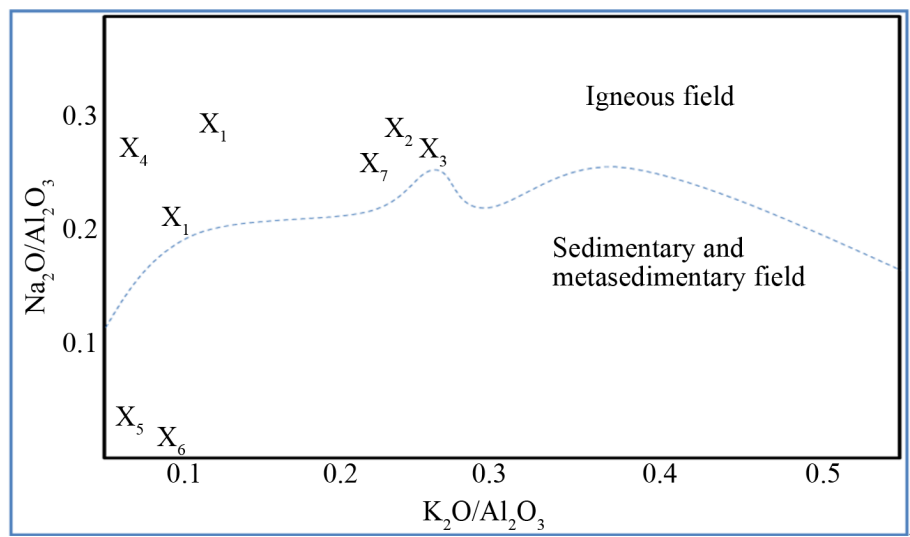

Figure 8. Alkali-Silica diagram of mafic rocks in the study area, modified after [20], $X_{1}$-banded gneiss, $X_{2}$-feldspathic gneiss, $X_{3}$-banded gneiss, $X_{5}$-phyllite, $X_{6}$-mica schist. 


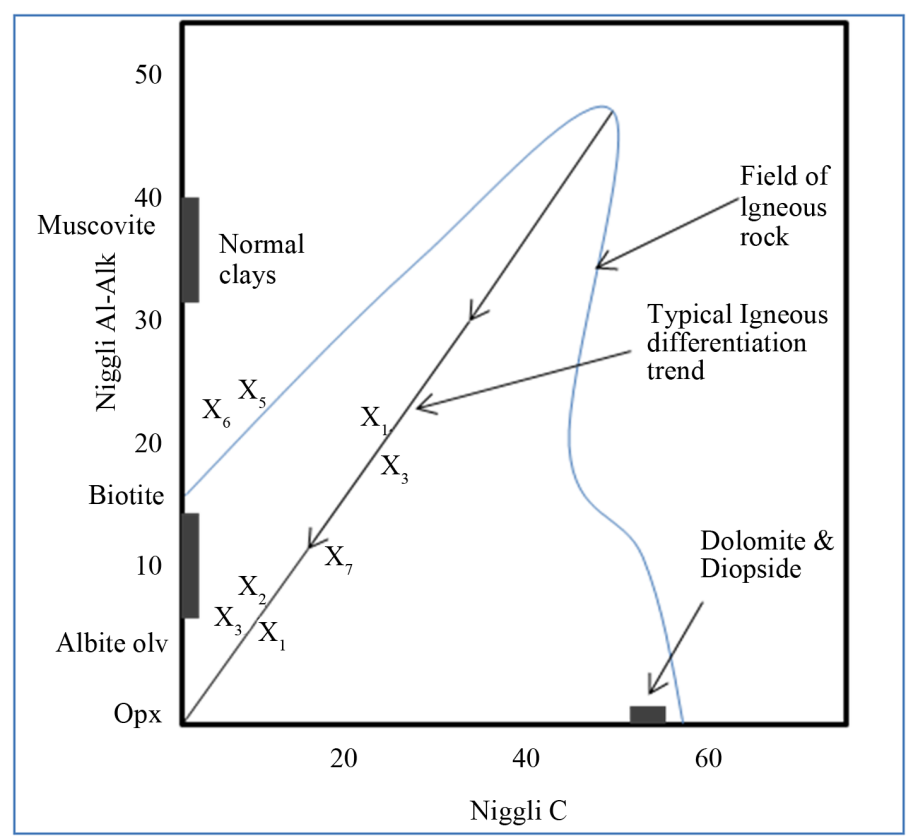

Figure 9. Niggli Al-Alk versus Niggli C diagram for rocks of the study area, modified after [23].

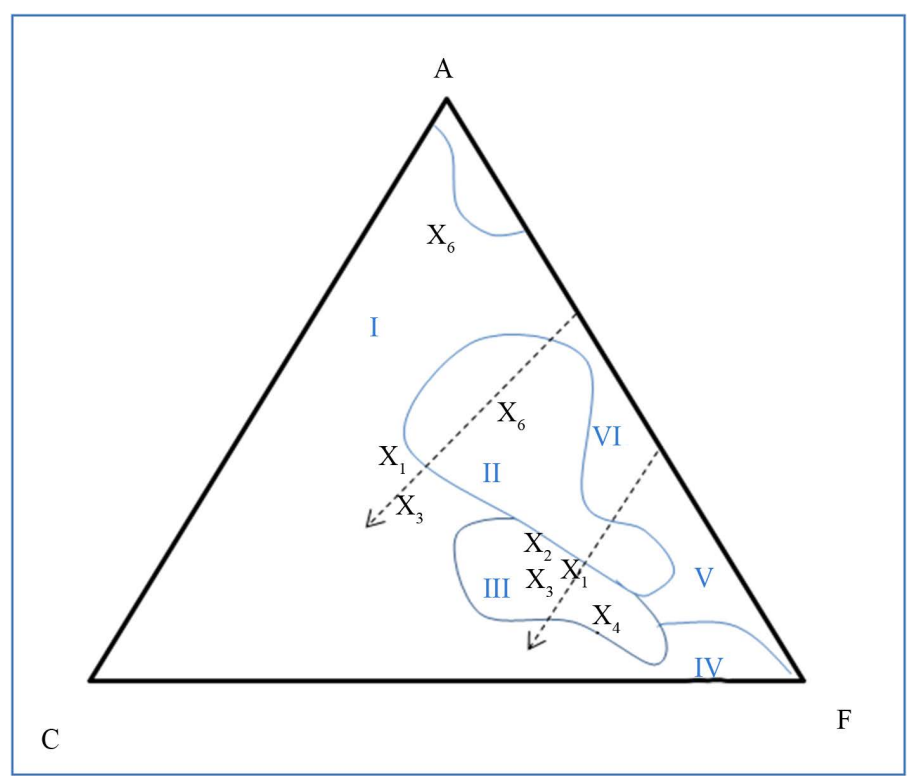

Figure 10. ACF diagram for determination of the chemical affinity of metamorphosed rocks of Okom-Ita area, modified after [21], $I=$ Clay-shales free of carbonate or containing up to $30 \%$ carbonate, $I I=$ greywacke, III = andesitic-basaltic field, $I V=$ ultra basic field, $V=$ clay or shale rich in carbonates, $\mathrm{VI}=\mathrm{Al}$-rich clays and shales.

indicative of the residual nature of magmatic melt. It is likely that most pegmatites owe their character to crystallization of either an anatectic melt or differential magma. It has been envisioned the pegmatites crystallize from hydrous granite magma [34], which were possibly emplaced during the main phase of Pan African Orogeny [3].

Dolerite must have been derived from basaltic magma, thus they are tholeiitic in composition. This primary basic magma may have been derived from the upper mantle at considerable depths. Their fine texture is a reflec- 
tion of the relatively shallow level of emplacement which favored fast cooling. They are unaffected by metamorphism and deformation. Their emplacement is believed to have terminated the Pan-African Orogeny in Nigeria [17]. Hence, they are often referred to be the youngest rock in the Oban Massif [35].

\section{Summary and Conclusion}

Detailed study of the petrology and geochemistry Basement Complex rocks in Okom-Ita area, Oban Massif, southeastern Nigeria, revealed that the dominant intrusive rocks in the area comprised of pegmatites, quartz veins and dolerites emplaced within gneiss, schist and phyllite host rocks. Amphibolite also occurs in the area. Bulk-geochemical rock analysis carried out using X-Ray fluorescence spectrometry, revealed that the geochemical properties of the rocks are a direct reflection of the characteristics observed in thin sections.

The gneisses, metasediments and pegmatites are dominated by quartz and feldspar, with subordinate biotite and plagioclase. The dolerites on the other hand are composed dominantly of plagioclase (45\%), olivine and pyroxene, with no quartz in their norm, reflecting their mafic character.

The chemical data (expressed in weight percent and molecular proportion) of the oxides were further plotted in chemical variation/discriminatory diagrams to determine their protoliths. The discriminant shows that the pegmatite was derived from late stage partial melting and differentiation of calc-alkaline magma, while the dolerite was generated from tholeiitic magma sources. On the alkali versus silica diagram, the dolerite plotted in the tholeiitic field corroborating origin from tholeiitic magma source. However, on the $\mathrm{TiO}_{2}-\mathrm{K}_{2} \mathrm{O}-\mathrm{P}_{2} \mathrm{O}_{5}$ diagram, the dolerite plotted in the field of continental basalt.

\section{References}

[1] Kroner, A., Ekwueme, B.N. and Pidgeon, R.T. (2001) The Oldest Rock in West Africa: SHRIMP Zircon Age for Early Archaean Migmatitic Orthogneiss at Kaduna, Northern Nigeria. The Journal of Geology, 109, 399-406. http://dx.doi.org/10.1086/319979

[2] Ekwueme, B.N. (1990) Rb-Sr Ages and Petrologic Features of Precambrian Rocks from the Oban Massif, Southeastern Ni- geria. Precambrian Research, 47, 271-286.

[3] Ekwueme, B.N. (2003) The Precambrian Geology and Evolution of the Southeastern Nigerian Basement Complex. University of Calabar Press, Calabar, 1-57.

[4] Okezie, C.N. (1974) Geological Map of Nigeria, Scale 1:2,000,000. Geological Survey of Nigeria, Abuja.

[5] Odeyemi, I. (1982) A Review of the Orogenic Events in the Precambrian Basement of Nigeria, West Africa. Geologische Rundschau, 70, 897-909. http://dx.doi.org/10.1007/BF01820170

[6] McCurry, P. (1976) The Geology of the Precambrian to Lower Paleozoic Rocks of Northern Nigeria—A Review. In: Kogbe, C.A., Ed., Geology of Nigeria, Elizabethan Press, Lagos, 15-39.

[7] Ferre, E., Deleris, J.I., Lar, A.U. and Peuct, J.J. (1996) The Pan-African Reactivation of Eburnean and Archaen Provinces in Nigeria: Structural and Isotopic Data. Journal of The Geological Society (London), 153, 719-728.

[8] Burke, K.C. and Dewey, F.J. (1972) Orogeny in Africa. In: Dessauvagie, T.F.J. and Whiteman, A.J., Ed., African Geology, Ibadan University Press, Ibadan, 583-608.

[9] Black, R., Caby, R., Pouchkine, A., Bayer, B., Bertrand, J.M., Boullier, A.M., Fabre, J. and Lesquer, A. (1979) Evidence for the Late Precambrian Plate Tectonics in West Africa. Nature, 278, 223-227. http://dx.doi.org/10.1038/278223a0

[10] Caby, R., Bertrand, J.M.I. and Black, R. (1981) Pan African Ocean Closure and Continental Collision in the HoggarIforas Segment, Central Sahara. In: Kroner, A., Ed., Precambrian Plate Tectonics, Elsevier, Amsterdam, 407-434.

[11] Ukaegbu, V.U. and Beka, F.T. (2007) Petrochemistry and Geotectonic Significance of Enderbite-Charnockite Association in the Pan-African Obudu-Plateau, Southeastern Nigeria. Journal of Mining and Geology, 43, 1-14.

[12] Rahaman, M.A., Ukpong, E.E.S. and Azmatullah, M. (1981) Geology of Parts of the Oban Massif Southeastern Nigeria. Journal of Mining and Geology, 18, 60-65.

[13] Ekwueme, B.N. (1983) Regional Metamorphism of Pellitic Rocks Southeast of Lokoja, Nigeria. Geology, 20, 71-77.

[14] Ekwueme, B.N. and Onyeagocha, A.C. (1985) Metamorphic Isograds of Uwet Area, Oban Massif Southeastern Nigeria. Journal of African Earth Sciences, 3, 443-454.

[15] Ekwueme, B.N. and Ekwere, S.J. (1989) The Geology of Eastern Section of Oban Massif, SE Nigeria. Journal of Mining and Geology, 25, 317-329.

[16] Ekwueme, B.N. (1993) An Easy Approach to Metamorphic Petrology. University of Calabar Press, Calabar, 169 p. 
[17] Ekwueme, B.N. and Shilling, H. (1995) Occurrence, Geochemistry and Geochronology of Mafic-Ultramafic Rocks in the Obudu Plateau, SE Nigeria. In: Srivastava, R.K. and Chandra, R., Eds., Magmatism in Relation to Diverse Tectonic Setting, Oxford \& IBH publishing Co. Pvt Ltd., New Delhi, 291-307.

[18] Niggli, P. (1948) Gesteine und Minerallgerstatten. Birkhauser, Basel, 540 p. http://dx.doi.org/10.1007/978-3-0348-7171-6

[19] Ehlers, E.G. and Blatt, H. (1982) Petrology: Igneous, Sedimentary and Metamorphic. W. H. Freeman, New York, 732.

[20] MacDonald, G.A. and Katsura, I. (1964) Chemical Composition of Hawaiian Lavas. Journal of Petrology, 5, 82-133. http://dx.doi.org/10.1093/petrology/5.1.82

[21] Winckler, H.G.P. (1967) Petrogenesis of Metamorphic Rocks. Springer-Verlag, New York, Inc., 237 p.

[22] Garrels, R.M. and Mackenzie, F.T. (1971) Evolution of Metasedimentary Rocks. Northern and Co., New York, 394 p.

[23] Leake, B.E. and Singh, D. (1986) The Delaney Dome Formation, Connemara, W. Ireland and the Geochemical Distinction of Ortho- and Para-Quartzofeldspathic Rocks. Mineralogical Magazine, 50, 205-215. http://dx.doi.org/10.1180/minmag.1986.050.356.03

[24] Pearce, T.H., Gorman, B.E. and Birkett, T.C. (1975) The $\mathrm{TiO}_{2}-\mathrm{K}_{2} \mathrm{O}-\mathrm{P}_{2} \mathrm{O}_{5}$ Diagram: A Method of Discriminating between Oceanic and Non-Oceanic Basalts. Earth and Planetary Science Letters, 24, 419-426. http://dx.doi.org/10.1016/0012-821X(75)90149-1

[25] Obioha, Y.E. and Ekwueme, B.N. (2012) Geochemistry of Schists of Northwest Obudu Plateau, Southeastern Nigeria. Global Journal of Geological Sciences, 10, 157-165.

[26] Rajamani, V., Krogstad, E.J., Hanson, G.N. and Balakrishnan, S. (1987) Are Patna and Bisansttam Granites (Adjoining the Kolar Schist Belt) Cogenetic. Geological Society of India, 30, 98-105.

[27] Obioha, Y.E. and Ekwueme, B.N. (2011) Petrology and Chemical Composition of Gneisses of Northwest Obudu Plateau, Southeastern Nigeria. Global Journal of Pure and Applied Sciences, 17, 215-226.

[28] Oyawoye, M.O. (1972) The Basement Complex of Nigeria. In: Dessauvagie, T.F.J. and Whiteman, A.J., Eds., African Geology, University of Ibadan Press, Ibadan, 67-99.

[29] Ekwueme, B.N. and Onyeagocha, A.C. (1985) Petrology of Intrusive Rocks in Uwet Area, Oban Massif, SE Nigeria. Journal of Mining and Geology,, 22, 71-78.

[30] Cox, K.G., Bell, J.D. and Pankhurst, R.J. (1979) The Interpretation of Igneous Rock. Allen \& Unwin, London, 450 p.

[31] Pettijohn, F.J. (1957) Sedimentary Rocks. 3rd Edition, Harper \& Row, New York, 628 p.

[32] Eskola, P. (1920) The Mineral Facies of Rocks. Norsk Geologisk Tidsskrift, 6, 143-194.

[33] Turner, F.J. and Verhoogen, J. (1960) Igneous and Metamorphic Petrology. 2nd Edition, McGraw-Hill, New York, 694 p.

[34] Jahns, R.H. and Burnham, C.W. (1969) Experimental Studies of Pegmatites Gneiss: A Model for the Derivation and Crystallization of Granitic Pegmatities. Economic Geology, 64, 843-864. http://dx.doi.org/10.2113/gsecongeo.64.8.843

[35] Ekwueme, B.N. (1998) Geochemistry of Precambrian Gneisses of Obudu Plateau, Southeastern Nigerian. Global Journal of Pure and Applied Sciences, 4, 277-282. 